with the rest of the body stiffened and suspended in mid-air, testified to violent and prolonged resistance. Some ants again had the body arched up, as if to avoid contact with the stem, and the legs only were fatally caught.

As is well known, the glutinous or sticky tracts lie around the stem directly beneath the nodes, and are about half an inch or more in depth. These glutinous zones are absent from the nodes, which are lower down on the stalk. But a darkening of the colour, just similar to what one sees below the sticky nodes, suggests the probability of these non-sticky nodes having been sticky at some former time.

I can find no reference in the ordinary books to the fact that ants visit, and die upon, this plant. In Smith's "English Botany," I 800 , however, occurs the following remarkable account of Lychnis viscaria:- "Stem straight, about a foot high, simple, angular, leafy, dark brown, and clammy under each joint, by which insects are plentifully caught, as in several other plants of the pink or campion tribe, for what purpose no one has yet ascertained; probably their decaying bodies form an air which is salutary to vegetable life." As I do not quite understand the author's meaning in the latter part of his remarks I naturally forbear criticising the statement, and mention it here merely to show the opinion of a botanist on the subject eightyone years ago.

On each flowering stem there are from two to four sticky nodes. I found that the majority of the deaths had occurred in the first zone of stickiness; fewer in the second, and still fewer at the higher nodes. Those ants therefore which gained the summit of their ambition would be pre-eminently strong and lusty, for to have arrived at the top of the plant among the flowers, they must have waded through morasses, each of which was sufficient to cause the death of many of their comrades. I found very few ants at the summit of the flowering stalks, and those that I did find there alive showed, from their want of vigour and restlessness, that they had been severely tried by the ordeals through which they had passed. The plant was growing in very rocky soil, each specimen quite isolated from any surrounding vegetation; so that I am satisfied that no ants, on the plants $\mathrm{I}$ examined, could have gained the summits by adventitious aids.

Time and the want of proper apparatus prevented my making some experiments I wished to have tried, and as I do not know when again I shall be able to pursue this most interesting investigation, your kind insertion of this may perhaps induce some of your readers to pursue the subject further. These are amongst the questions which have occurred to me:-(I) Is there any attraction in the glutinous secretion, or does the attraction lie in the flowers? I saw no ant-hills or nests anywhere in the neighbourhood of the flowers, and my impression at the time was that the ants had come a long distance. I scrutinisingly examined the ground, and, to my astonishment, found that almost the only ants on the spot were upon the plants. (2) How is it, if these sticky zones are simply to prevent ants and other small walking animals from getting to the flowers, that they do not occur at the lower part of the stem as well as higher up? (3) What injury, if any, do ants cause to this plant? (4) Is it likely that the plant derives direct benefit from the deaths that take place upon it? Is there, in short, any digestive action in the glutinous secretion, and any absorptive power in those portions of the stem where it is found?

I brought home some specimens showing the dead bodies of ants stuck to the flower stalks, and these were exhibited at the last meeting of the Linnean Society. I shall be happy to show them to any who are interested in the subject. J. HARRIS STONE

I I, Sheffield Gardens, Kensington, December 2

\section{Solar, Gas-Flame, and Electric-Light Spectra}

IN answer to Mr. J. Hopkins Walters' inquiry contained in NATuRE, vol. xxv. p. 103, the spectroscope declares that all these three spectra have for their base a continuous strip or band of light; in the case of gas-flame (the bright part) crossed by the sodium lines only; in that of the sun by the well-known Frauenhofer dark lines; and of the electric (arc) light by the bright lines of carbon. The illuminating power of each of these sources of light is thus shown to be due to the incandescence of their several solid and gaseous constituents, concerning which a volume might be written. The relative effect of the sun's bright golden glare, the gas-flame's duller yellow tint, and the electriclight's moon-like whiteness, on the optic nerve; have not, as far as I am aware, been yet made the subject of special research. Popular opinion assigns injurious results to the whiter light. Mr. Walters will find in "Photographed Spectra," on Pl. xv., Fig. 4, and the extra plate, the solar spectrum, and on Pl. v., Figs. 3 and 4 , the spectrum of the electric arc between carbon points specially prepared to insure purity. In Dr. Marshall Watt's "Index of Spectra" the spectrum of the blue base of candle-flame is represented by the graphical diagram and description, Carbon I. The illuminating portion of a gas-flame presents in the spectroscope the appearance of a dull sun spectrum without the dark lines.

Guildown, December 3

\section{Tele-dynamics and the Accumulation of Energy-their} Application to the Channel Tunnel

A REMARKABLE opportunity is now presented to electrical and mechanical engineers of applying to eminent practical service the recent discoveries and advances made in relation to the accumulation and transmission of energy in the form of electricity. I allude to the construction and working of the Channel Tunnel Railway. Of course the direct application of steampower to the work of boring is out of the question. The power employed in boring Mont Cenis and St. Gothard was transmitted by compressed air through metal tubes, but this is a very costly, wasteful, and in some respects inconvenient process ; and this cost and waste increases in a very high ratio to the distance of transmission. Since those works were executed an immense advance has been made in the practice of transmitting energy by electric current, and particularly in storing that energy; and I predict that if the tunnel is ever completed (which I do not doubt) it will be by means of electrical agency. An eminent civil engineer, who had invented a boring-machine which he considered of great promise for that work, told me more than a year ago that Dr. Siemens assured him that he would undertake to transmit 50 per cent. of the initial power by electric current half way through the tunnel; and by this time he would most probably give a much larger percentage. An eminent French authority promises from sixteen to twenty horse-power by a single current over a distance of from ten to fifty kilometres. If these statements are founded on fact your readers will at once realise the applicability and potency of the agent. Then there must of necessity be an immense quantity of material to be carried to and fro. The electrical railways of Berlin, Brussels, and Paris have left no question open as to the easiest and most economical means of propelling the trollies; and by using several conductors as many trolly trains in succession could be run as there would be conductors. It would be premature to discuss now the subject of working this railway, but it is certain that electricity will be the agent, and there is very little doubt that the twenty miles of level tunnel way will be worked by energy generated and stored by the train itself in its descent from the land level to the tunnel level. An examination of this question in detail would be incompatible with your space and purpose. I will simply say that a train of IOo tons descending a gradient of $r$ in 100 for five miles would start with a potential force of nearly $60,000,000$ foot pounds, a very small portion of which would be expended in useful work. Let the surplus of this be applied not to destroy. ing the rails by brakes and conversion into useless heat, but by revolving generators and storing the product to be used in again turning the generators (now motors) for propelling the train. I do not say that the train could be lifted up the five miles at the other end by this stored energy : the engineers may be intrusted with that duty.

Tottenham

E. WALKER

Johnston LAvis.-Your paper wants beginning and title. Please send.

Dante AND the Southern Cross.-A correspondent inquires where Dante could have learned about the Southern Cross, to which there is evident allusion in the first canto of the "Purgatorio."

\section{FAMAICA}

$\mathrm{F}$ all the West Indian Colonies appertaining to the British Crown, that of the Island of Jamaica can claim to be the largest in area, the most numerous in population, and the wealthiest in revenue. Within half a 